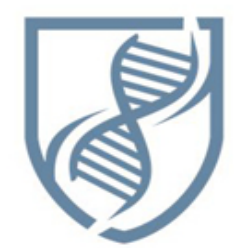

Journal of Bioscience and Applied Research

\section{JBAAR}

WWW.JBAAR.ORG

\title{
Biochemical study of some non invasive markers in liver fibrosis patients
}

\author{
Ayman E. El Agroudy ${ }^{1}$, Mohamed S. Elghareb ${ }^{2}$, Emad H. Elshahat ${ }^{3}$, \\ Ezar H. Hafez ${ }^{4}$, Tamer A. Addissouky ${ }^{5}$ \\ ${ }^{1}$ ( Department of Medical Biochemistry, Faculty of Medicine, Mansoura University, Mansoura, Egypt ); ${ }^{2,5}$ ( Department \\ of Chemistry, Faculty of Science, Port Said University, Port Said, Egypt ); ${ }^{3}$ (Gastrointestinal Surgery Centre, Faculty of \\ Medicine, Mansoura University, Mansoura, Egypt); ${ }^{4}$ (Department Of Zoology, Faculty of Science, Tanta University, \\ Tanta, Egypt); \\ (Corresponding author e.mail. tedesoky@gmail.com)
}

\begin{abstract}
Non-invasive methods have been proposed as surrogate markers for liver biopsy. It was shown that serum hyaluronic acid (HA) level increase with the development of liver fibrosis. The present study aims to determine serum HA level cut-off points for predicting liver fibrosis. Serum HA level in chronic hepatitis patients $(n=60)$ are divided into two groups, group1: included 30 patients, there were positive for anti-HCV (antibodies), group2: included 30 patients, there were positive for HBsAg, and controls $(n=10)$ were assessed by ELISA and liver histopathological parameters were evaluated by the modified Knodell score and microscopic examination of liver biopsies. The results showed that individuals in healthy control group have normal levels of HA (mean 14.3, SD: 5.5) while the levels of HA were elevated in patients of HCV alone (mean 103.6 \pm 28.0 ) and in patient of HCV (mean 104.5 \pm 37.5).Also levels of HA were poorly elevated in HBV alone (mean 62.2 \pm 15.5) and in HBV (mean 45.8 \pm 12.4). The comparison between the studied groups regarding to the level of HA showed that a significant difference was observed between healthy group and $\mathrm{HBV} \& \mathrm{HCV}$ groups $(\mathrm{P}<$ 0.001).HA levels and stages of fibrosis were well correlated in patients of $\mathrm{HBV}$ and $\mathrm{HCV}$ group. Where, this is a significant increase in HA levels
\end{abstract}

when considering F0 to F6 scores by liver biopsy ( $\mathrm{P}$ $<0.001)$. Serum HA levels are well correlated with HAI In patients Of HBV \& HCV groups where, there was significant increase in HA levels by increase of $\mathrm{HAI}$ in liver biopsy at $\mathrm{P}<0.001$.

Keywords: Chronic hepatitis; Liver fibrosis; Hyaluronic acid; Liver biopsy.

\section{Introduction}

Liver fibrosis is a complex process involving production and deposition of insoluble components that constitute the extra-cellular matrix (ECM).These components can be divided into collagens ( type I and II being predominant in the liver ), non collagenous glycoproteins ( fibronictin , laminin , undulin and elastin ), proteoglycans ( heparin and dermatan sulfate ), and polysaccharide as hyaluronic acid (Gressner , 1994). Major causes of fibrosis and cirrhosis include chronic viral hepatitis and parasitic injuries (cirrhosis and fibrosis) (Kaplowitz, 1996). Certain case conditions are due to inborn errors of metabolism, for example, hemochromatosis, and hepatocellular degeneration (Gressner and Schuppan, 1999).Liver biopsy remains the golden standard to assess fibrosis several system for scoring liver fibrosis have been proposed, each based upon visual assessment of portal and periportal fibrosis (Alberto, and Bortolotti ,1999). Some biochemical tests do not reliably predict the stage of fibrosis. Currently available, indirect serum markers of fibrosis are not 
reliable, particularly in discriminating between mild and moderate degree of fibrosis (Tong et al., 1995).Serum hyaluronic acid reflects the severity of hepatic inflammation and may be a serological marker of fibrosis and can be used as a serological marker of fibrosis (Bramley et al., 1991). Therefore we aimed to determine the differences in the serum concentration of hyaluronic acid between patients (chronic hepatitis B and C patients) with liver fibrosis according to the microscopic examination of liver biopsies from patients and healthy individuals without any sign of liver disease, as well as the optimal cut-off values for discriminating patients with liver fibrosis from those without liver fibrosis and patients with mild fibrosis from those with severe fibrosis.

\section{Materials and Methods Subjects}

This study was conducted on 60 chronic viral hepatitis patients and 10 healthy individuals attending out patients' clinic of Gastrointestinal Surgery Centre, Mansoura University for follow up. According to viral hepatitis markers, subjects were divided into 2 groups: Group 1: included 30 patients, they were positive for anti-HCV (antibodies). Group 2: included 30 patients, they were positive for HBsAg .Blood and liver biopsy tissue specimen samples were obtained from studied patients and were subjected to the following lab-tests: 1. Immunological assays.2. Biochemical assays. -3. Molecular biology techniques. -4. Tissue histological assays.

\section{Blood sampling:}

Five ml venous blood sample were withdrawn from every subject by aseptic venipuncture from an anticubital vein in a fasting state. The blood was left to clot in incubator for $15 \mathrm{~min}$. then centrifuged and the separated serum was collected in sterile tube; liver function tests including serum ALT and AST, serum ALB (Heidelbaugh and Bruderly, 2006)., Detection of anti-HCV antibody using enzyme linked immunosorbentassay (ELISA) :Antibodies to hepatitis $\mathrm{C}$ virus (HCV) were qualitatively determined by using ETI-AB-HCVK-3 (P00626) Sorin Biomedica kit (Sorine Biomedica, Diagnostic Division, 1304, Suluggia, Vercelli, Italy) (Rihn etal., 2000). Pathological processing for liver biopsy specimens was as follows, 4 u sections were prepared from paraffin blocks and stained for hematoxyline and eosin stain (H \& E), massontrichrom, reticulin, periodic acid Schiff stain (PAS) and PAS- diastase stains (Bancroft and Stevens., 1975). Prepared slides from liver biopsy specimens were examined. Degree of stage of fibrosis were assessed according to (Knodell et al., 1981).Histological activity index (HAI) was based upon assessment of portal inflammatory infiltrate, interface hepatitis and parenchymal necrosis, with score range from 0-18.
Fibrosis was scored separately on a scale of 0-6, corresponding to absent fibrosis up to cirrhosis.

\section{Statistical Analysis:}

Data were obtained using Statistical package for social Sciences (SPSS) version 19.0 software. Data were expressed as means \pm standard deviation (SD) .Results of HCV patients and control subjects were performed using chi- square analysis, way a nova, and independent t-test. Correlation between parameters was determined by Pearson's correlation coefficient (r). Chi square and odds ratio were calculated with $95 \%$ confidence interval .A p- value less than 0.05 was considered statistically significant.

\section{Results}

The biochemical data of the studied groups showed that no significant difference between healthy group and HBV group regarding serum ALT and serum AST $(\mathrm{P}=$ 0.06 , 0.13, respectively) (Table 1 ). There was a statistically significant difference between healthy group and HCV group regarding to ALT and AST levels $(\mathrm{P}<0.001)$. Patients in HCV group showed higher serum ALT and AST values than those observed in healthy group and HBV group $(\mathrm{P}<0.001)$ as shown in table 2 . Table 1, 2 showed no significant difference was observed among the studied group regarding serum albumin. Table 3 showed comparison between HBV group and HCV group according to biochemical characters and significant difference is observed. Table 4 showed levels of HA in serum samples of the studied groups. Individuals in healthy control group have normal levels of HA (mean 14.3, SD: 5.5) while the levels of HA were elevated in patients of HCV alone (mean 103.6 \pm 28.0 ) and in patient of HCV (mean 104.5 \pm 37.5). Also levels of HA were poorly elevated in HBV alone (mean 62.2 \pm 15.5) and in HBV (mean 45.8 \pm 12.4). Table 5 showed no significant difference was observed between $\mathrm{HCV}$ and $\mathrm{HBV}$ group regarding level of serum HA. Comparison between mild fibrosis and significant fibrosis regarding to HA levels showed highly significant difference $(\mathrm{P}<0.001)$ in both HBV \& HCV groups (Table 6).

Serological tests for hepatitis B virus and hepatitis $C$ virus: All patients of HBV group were positive for HBsAg. While all individuals in healthy control group and HCV patients group were negative for HBsAg (Figure 1). All patients of HCV group were positive for anti-HCV antibodies, while all individuals of healthy group and HBV group were Negative for anti-HCV antibodies (Figure 2).

The percentage of significant fibrosis (F3 - F6) was $8 \%$ in patients of group HBV while $19.5 \%$ in patients of group $\mathrm{HCV}$. Also the percentage of non significant fibrosis (F0, F2) was 92\% in patients of HBV group, while $80.5 \%$ in $\mathrm{HCV}$ group (Figure 3).Figure 4, 5 
showed that HA levels and stages of fibrosis were well correlated in patients of $\mathrm{HBV}$ and $\mathrm{HCV}$ group. Where, this is a significant increase in HA levels when considering F0 to F6 scores by liver biopsy ( $\mathrm{P}<$ 0.001).Figure 6: showed that there was no significant difference $\mathrm{P}=0.50$ regarding to HA levels in patients with $\mathrm{HBV}$ alone and HBV or in patients with $\mathrm{HCV}$ alone and HCV.

Table 1: Comparison between healthy group and HBV group according to biochemical characteristics. * Significance: $<0.05 *$ Significance: $<0.05$

\begin{tabular}{|l|l|l|l|}
\hline $\begin{array}{c}\text { Biochemic } \\
\text { al } \\
\text { parameters }\end{array}$ & $\begin{array}{c}\text { Healthy } \\
\text { group } \\
\text { Median } \\
\text { (Range) }\end{array}$ & $\begin{array}{c}\text { HBV group } \\
\text { Median } \\
\text { (Range) }\end{array}$ & P value \\
\hline $\begin{array}{c}\text { Serum AL } \\
\mathrm{T}(\mathrm{u} / \mathrm{ml})\end{array}$ & $\begin{array}{c}24.0(13 \\
-34)\end{array}$ & $28.0(19-34)$ & $0.06^{* *}$ \\
\hline $\begin{array}{c}\text { Serum AST } \\
(\mathrm{u} / \mathrm{ml})\end{array}$ & $\begin{array}{c}21.0(11 \\
-29)\end{array}$ & $26.0(14-35)$ & $0.13^{* *}$ \\
\hline $\begin{array}{l}\text { Serum Alb } \\
\text { umin (g/dl) }\end{array}$ & $\begin{array}{c}4.4(4.1- \\
4.8)\end{array}$ & $4.4(3.9-5.0)$ & $0.86^{* *}$ \\
\hline
\end{tabular}

Table 2: Comparison between healthy group and HCV group according to biochemical characteristics. * Significance: $<0.05 * *$ Not Significance: $>0.05$

\begin{tabular}{|c|l|l|l|}
\hline $\begin{array}{c}\text { Biochemical } \\
\text { parameters }\end{array}$ & $\begin{array}{c}\text { Healthy gr } \\
\text { oup } \\
\text { Median (R } \\
\text { ange) }\end{array}$ & $\begin{array}{c}\text { HCV grou } \\
\text { pedian }(\mathrm{R} \\
\text { ange) }\end{array}$ & P value \\
\hline $\begin{array}{c}\text { Serum ALT ( } \\
\mathrm{u} / \mathrm{ml})\end{array}$ & $\begin{array}{c}24.0(13- \\
34)\end{array}$ & $\begin{array}{c}69.0(18- \\
280)\end{array}$ & $\begin{array}{c}<0.001 \\
*\end{array}$ \\
\hline $\begin{array}{c}\text { Serum AST ( } \\
\mathrm{u} / \mathrm{ml})\end{array}$ & $\begin{array}{c}21.0(11- \\
29)\end{array}$ & $\begin{array}{c}48.0(25- \\
200)\end{array}$ & $\begin{array}{c}<* .001 \\
* *\end{array}$ \\
\hline $\begin{array}{c}\text { Serum Albu } \\
\mathrm{min}(\mathrm{g} / \mathrm{dl})\end{array}$ & $4.4(4.1-$ & $4.3(3.8-$ & 0.58 \\
& $4.8)$ & $5.1)$ & \\
\hline
\end{tabular}

Table 3: Comparison between HBV group and HCV group according to biochemical characteristics.

$*$ Significance: < $0.05 * *$ Not Significance: $>0.05$

\begin{tabular}{|c|c|c|c|}
\hline $\begin{array}{c}\text { Biochemical parameter } \\
\mathrm{s}\end{array}$ & $\begin{array}{c}\text { HBV group } \\
\text { Median (Range) }\end{array}$ & $\begin{array}{c}\text { HCV group } \\
\text { Median (Range) }\end{array}$ & P value \\
\hline Serum ALT (u/ml) & $28.0(19-34)$ & $69.0(18-280)$ & $<0.001^{*}$ \\
\hline Serum AST (u/ml) & $26.0(14-35)$ & $48.0(25-200)$ & $<0.001^{*}$ \\
\hline Serum Albumin (g/dl) & $4.4(3.9-5.0)$ & $4.3(3.8-5.1)$ & 0.48 \\
\hline
\end{tabular}

Table4: Characteristics of serum hayluronic acid among the studied groups.

\begin{tabular}{|c|c|c|c|}
\hline $\begin{array}{c}\text { Biochemical parameter } \\
\text { s }\end{array}$ & $\begin{array}{c}\text { HBV group } \\
\text { Median (Range) }\end{array}$ & $\begin{array}{c}\text { HCV group } \\
\text { Median (Range) }\end{array}$ & P value \\
\hline Serum ALT (u/ml) & $28.0(19-34)$ & $69.0(18-280)$ & $<0.001^{*}$ \\
\hline Serum AST (u/ml) & $26.0(14-35)$ & $48.0(25-200)$ & $<0.001^{*}$ \\
\hline Serum Albumin (g/dl) & $4.4(3.9-5.0)$ & $4.3(3.8-5.1)$ & 0.48 \\
\hline
\end{tabular}

Table 5: Comparison between HBV group and HCV group according to serum HA.

** Not Significance: $>0.05$

\begin{tabular}{|l|r|r|l|}
\hline & HBV group & HCV group & P value \\
& Mean \pm SD & Mean \pm SD & \\
\hline $\begin{array}{c}\text { Hayluronic } \\
\text { acid }\end{array}$ & $57.6 \pm 16.5$ & $103 \pm 37.5$ & $0.97^{* *}$ \\
\hline
\end{tabular}

Table 6: Comparison between mild fibrosis and significant fibrosis in the studied groups according to HA level

\begin{tabular}{|c|c|c|c|}
\hline \multirow{2}{*}{ Studied groups } & \multicolumn{2}{|c|}{ Level HA in fibrosis stages } & \multirow{2}{*}{$\mathrm{P}$} \\
& $\begin{array}{c}\text { Non- } \\
\text { Significant fibro }\end{array}$ & Significant fibro & \multirow{2}{*}{} \\
\cline { 2 - 4 } & & $188 \pm 161.6$ & $<0.001$ \\
\hline HCV & $23.5 \pm 14.7$ & & \\
\hline HBV & $33.9 \pm 22.1$ & $118 \pm 91.6$ & $<0.001$ \\
& & & \\
\hline
\end{tabular}




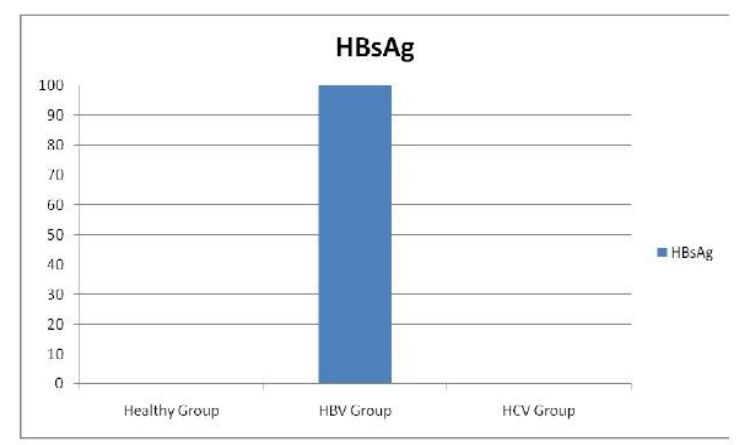

Figure 1: Serological marker of hepatitis B virus among $t$ he studied Groups.

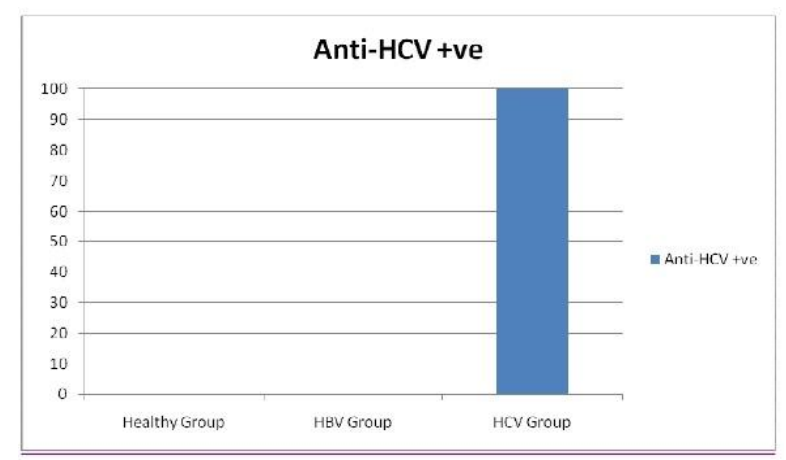

Figure 2: Serological marker of hepatitis C virus (antiHCV antibodies) among the studied groups

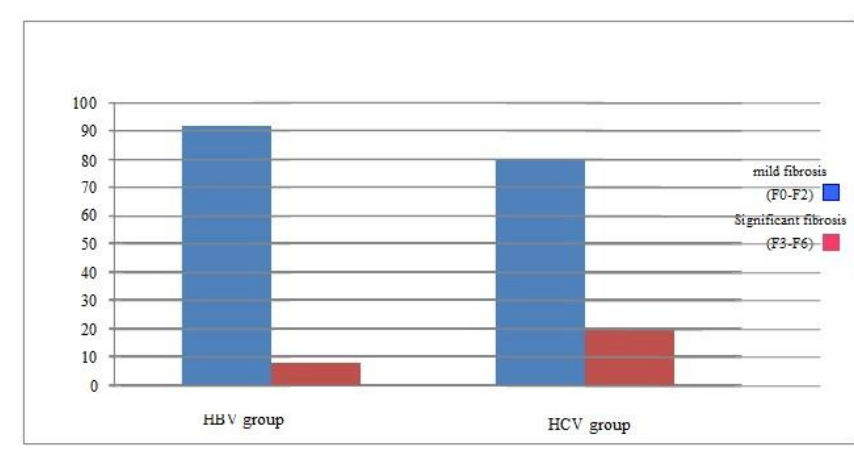

Figure 3: Percentage of significant fibrosis in patients of the studied group according to fibrosis grades.

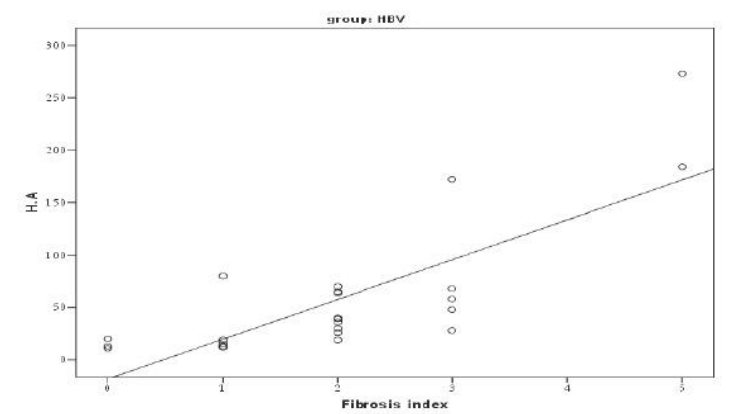

Figure 4: Correlation between level of HA and fibrosis st age in patients of HBVgroup

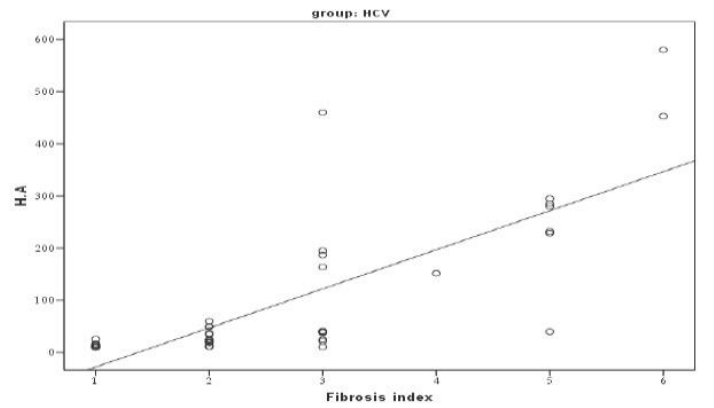

Figure 5: Correlation between level of HA and fibrosis stage in patients of $\mathrm{HCV}$ group.

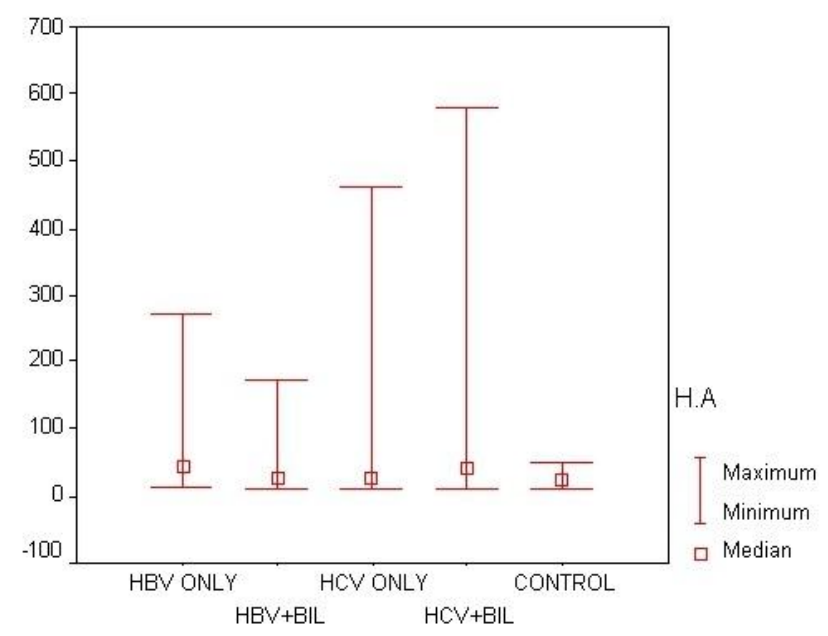

Figure 6: correlation of HA among the studied groups.

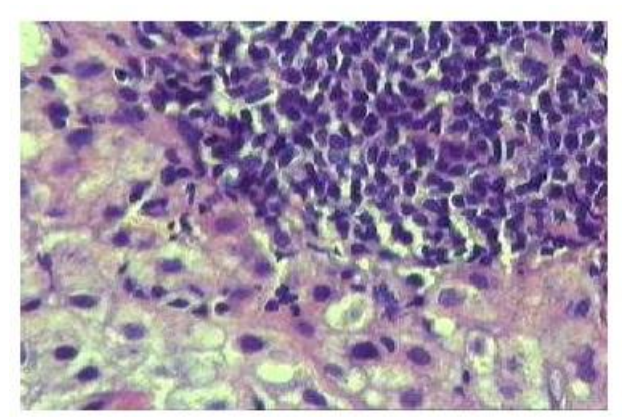

Figure 7: HCV liver biopsy showed desne portal infiltrate with mild interface hepatitis (H \& E 400).

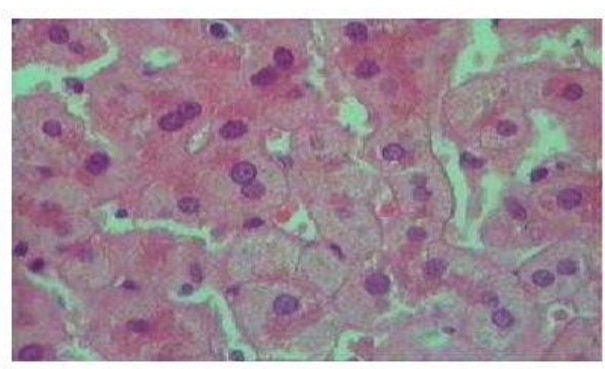

Figure 8: HBV liver biopsy showed evident ground glass pattern of hepatocytes (H \& E 400). 
Patients of group C revealed variable portal lymphocytic infiltrate with occasional bile duct injury. Some showed dense infiltrate (Figure 7), interface hepatitis as well parenchymal focal necrosis were seen in variable proportions. Patients of group showed similar histopathological changes to $\mathrm{HCV}$, however with less evident portal infiltrate and lacking bile duct injury and the diagnostic feature of Hepatitis $\mathrm{B}$ is a ground glass cytoplasm (Figure 8)

\section{Discussion}

Viral hepatitis is still a major health problem particularly in developing countries with low standards of environmental sanitation. HBV and HCV infections account for a substantial proportion of the cases of chronic liver disease including chronic hepatitis, cirrhosis and liver cancer (Kao and Chen., 2000). HBV is one of the most common pathogens in the world. Annually up to 1 million people die due to the consequences of this infection such as cirrhosis. Mast et al., (1999) found that $12 \%$ of Egyptian patients with chronic liver disease were positive of HBsAg. Among important hepatitis associated risk factors reported were parenternal injection, dental manipulation and hospitalization. Blood transfusion seemed to have very minor role (Farghaly and Barakat., 1992).The courses and outcomes of chronic hepatitis B virus infections were quite variable. Milder forms were non-progressive or only slowly progressive and were usually accompanied by the loss of serum HBV DNA and sero conversion from hepatitis $\mathrm{B}$ envelop antigen to envelop antibody (anti-HBe) (Kreutz 2002). Manno et al., (2002) found no significant different regarding the survival of liver related deaths between chronic asymptomatic HBsAg carriers and controls after thirty years of follow up. In this study, hepatic transaminasis in patients of group B were normal in $97 \%$ of chronic HBV patients and all patients were positive for HBV DNA using PCR. this in agreement with Lindh et al., (2000 ) who found that using PCR assays, the majority of patients with chronic $\mathrm{HBV}$ infection, including those who are hepatitis Be antibody positive have detectable HBV DNA.HCV is a small enveloped RNA virus that is responsible for more than $90 \%$ of cases of partially transmitted non A, non B hepatitis (Cuthbert, 1997). Although acute infection with HCV may be asymptomatic, HCV infection can cause chronic liver disease such as chronic hepatitis and cirrhosis (Choo et al., 1987) and is involved in the hepatocellualr carcinoma. Min et al. (2005) reported that serum levels of HA increase in patients with schistosomiasis compared to their healthy counterparts, HA is an ideal single index for diagnosing hepatic fibrosis according to a previous study on the relationship between serum fibrosis indices and liver histological changes. However, while HA reflects the degree of active fibrosis, it fails to indicate the level of fibrosis formed in the liver. Hyaluronan is a better fibrosis marker than laminin to diagnose children with advanced liver fibrosis (Xie et al., 2003).The significant decrease of hyaluronan level during therapy suggests anti- fibrotic effect of lamivudine in children with CHB (Lebenstejen DM et al., 2007). Pascal et al., (2000) reported that, lipid peroxides and protein carbonyl, as well as Hyaluronic acid levels increased with the grade of fibrosis. Moreover, protein carbonyl and hyaluronic acid levels correlated positively with lipid peroxide levels. These findings indicate that oxidative stress might contribute to S. mansoni-associated pathology in man. The result of the present study was in consistent with Kopke-Aguiar et al., (2002) who reported that serum hyaluronic acid is a good marker for the initial phase of hepatic fibrosis and it was able to assess severity of liver disease in schistosomiasis. Also, Kopke-Aguiar et al. (2002) mentioned that, inclusion of the serum hyaluronic acid determination may be helpful to the calculation of the indices to evaluate, without the need for a liver biopsy, the evolution of fibrosis in patients within a risk group (schistosomiasis, alcohol, virus). HA and Hepascore cannot accurately stage hepatic fibrosis in this population. Locally derived, disease-specific cut-offs for HA gave the higher diagnostic efficiency observed. Although HA and Hepascore may be useful where the disease etiology is known, particularly in established hepatitis $C$ virus, the high cost of false positives and false negatives are such that neither a reliable enough to replace biopsy without substantial further characterization (Costelloe et al., 2015). Cross-linked high-molecularweight HA had positive effects on the prevention of epidural fibrosis and the reduction of fibrotic tissue density. The efficacy of this agent should also be verified in further experimental and clinical studies (Is1k et al., 2015). The increasing of HA level in our patients may be due to liver fibrosis which is the result of the imbalance between synthesis and degradation of the extracellular matrix. HA is one of the major components of the extracellular matrix glycosaminoglycan, often as the detection indicator of liver fibrosis. HA can accurately reflect that the liver has generated fiber volume and status of liver cell damage. When chronic liver damage takes place, synthesis of HA is increased and the degradation is reduced, so that HA content in serum is increased and HA content is also correlated with the stage of hepatic fibrosis (Wang and liang, 2010). Non-overlapping confidence intervals of biological variation estimates allowed us to detect significant differences regarding hyaluronic acid biological variation between chronic liver disease subgroups (Istaces and Gulbis, 2015). This, lead one to suggest that HA is a good biochemical Marker for hepatic fibrosis. 


\section{Conclusion}

Our findings suggest that measurement of serum HA concentration can discriminate between patients with liver fibrosis and healthy individuals and between patients with mild fibrosis and those with severe fibrosis. An increase in serum HA concentration above the predictive value is associated with liver fibrosis. In addition the values of the APRI score and serum HA level are in the same order. Therefore, serum HA level with the APRI score could be an additional non-invasive tool for evaluation of liver fibrosis, when liver biopsy is contraindicated.

\section{Competing interests}

Authors have declared that no competing interests exist.

\section{References}

Alberto A and Bortolotti F (1999). Viral infection of liver.Hepatitis C, Bircher J,Benhamou JP, Mcintyre N, et al, 9eds). Textbook of clinical Hepatology. Oxford University Press.

Bramley PN, Rathbone BJ, Forbes MA, Cooper E H, Losowsky MS (1991).Serum hyaluronate as a marker o $\mathrm{f}$ hepatic derangement in acute liver damage.

J Hepatol. 13:8-13.

Bancroft and Stevens (1975). Histopathological stains and their diagnostic uses (Hardcover), Elsevier Health Science. 192-193.

Weiner AJ,Overby LR, Bradley DW and Houghton M (19 87).Isolation of a cDNA clone derived from blood-

borne non-A, non- B viral

hepatitis genome. Science. 244: 359- 362.

Costelloe SJ , Theocharidou E, Tsochatzis E, Thalassinos E, Martin N, Fede G, Thomas M, Burroughs AK ( 2015). Hepascore and hyaluronic acid as markers of fibrosis in liver disease of mixed aetiology. Eur J Gastroenterol Hepatol. (3):313-20.

Cuthbert JA (1997). Hepatitis C: progress and prob lems. Clin. Microbiol. Rev. 7: 505 - 532.

Farghaly AG and Barakat RM (1992).Association between chronic hepatitis B Carrier state and schistosomiasis. J. Egypt Public Health Assoc. 67(56):607-21.

Gressner AM and Schuppan D (1999). Cellular and molecular pathobiology,pharmacological ntervention and biochemical assessment of liver fibrosis. InBircher J,Beh amou JP, Meintyre N et al 9eds)Textbook of clinical hepatology, Oxford Press.

Gressner Am. (1994). Activation of proteoglycan synthesis in injured liver-a brief review of molecular and cellular aspects. Eur J Clin. Chem Biochem. 32:225.

Heidelbaugh J and Bruderl M (2006). Cirrhosis and Chronic Liver Failure: Part I. Diagnosis and Evaluation. Am Fam Physician; 74(5):756-762.
Istaces N and Gulbis B( 2015). Study of FibroTest and hyaluronic acid biological variation in healthy volunteers and comparison of serum hyaluronic acid biological variation between chronic liver diseases of different etiology and fibrotic stage using confidence intervals. Clin Biochem. 48(10-11):652-7

Isık S, Taşkapılıoğlu MÖ, Atalay FO, Dogan S( 2015). Effects of cross-linked high-molecular-weight hyaluronic acid on epidural fibrosis: experimental study.J Neurosur Spine.22(1):94-100.

Kao JH and Chen DS (2000). Overview of hepatitis B and C viruses. p.313 - 330. In J.J.Goedert (ed.) "Infectious causes of cancer : targets for intervention. Humana Press Inc., Totowa., N.J. USA.

Kaplowitz N (1996). Liver and biliary disease, ed 2 Philadelphia, Williams \&Wilkins.

Kreutz C (2002). Molecular, immunological and clinical properties of mutated hepatitis B viruses. J. Cell. Mol. Med.6 (1):113-143.

Knodell RG, Ishak KG, Black WC, Chen TS, Craig R, Kaplowitz N, Kiernan TW and Wolman J (1981). Formulation and application of a numerical scoring system for assessing histological activity in asymptomatic chronic active hepatitis. J. Hepatology. 1(5):431-5.

Kopke-Aguiar LA, Martins JRM, Passerotti CC, Toledo CF, Nader HB and Borges DR. (2002). Serum hyaluronic acid as a comprehensive marker to assess severity of liver disease in schistosomiasis. Acta. Tropica. 84 : 117-126.

Lebenstejen DM, Skiba E, Sobaniec Lotowska ME, Kaczmarski M (2007).Serum hyaluronan and laminin level in children with chronic hepatitis B during long-term lamivudine treatment. Hepatogastroenterolgy. 54:834-8.

Lindh M, Horal P, Dhillan AP and Norkrans G (2000). Hepatitis B virus DNA levels, precore mutations, genotypes and histological activity in chronichepatitis B. J viral hepatitis. 7: 258-267.

Manno M, Grottola A and Ferretti I (2002).Thirty year's follow-up of chronic asymptomatic HBsAg carriers: Importance of occult infections. J. Hepatol. 36 (1): 7.

Mast EE, Alter MJ and Margolis HS (1999). Strategies to prevent and control hepatitis B and C virus infections. a global perspective. Vaccine. 17:1730.

Min Z, Wei-Min C, Shao-Ming Z, Rong-Hua L (2005). Determination of serum levels of YKL-40 and hyaluronic acid in patients with hepatic fibrosis due to schistosomiasis japonica and appraisal of their clinical value. Acta Tropica 96: 148-152.

Rihn B., Hussenet F., Detry MB., Catelle A and Faou AL (2000). Evaluation of a supplemental assay for the diagnosis of hepatitis $\mathrm{C}$ virus infections. Int. J.Infect. Dis.; 4(1):42-5. 
Tong MJ, El-Farra NS, Reijes Ar, et al (1995). Clinical outcomes after transfusion associated hepatitis C. N Engl J Med.332:1463.

Xie S B, Yao, J L, Zheng R Q, Peng X M, and Gao Z L (2003). Serum hyaluronic acid, procollagen type III and IV in histological diagnosis of Liver fibrosis. Hepatobiliary Pancreat Dis. Int. 2: 69-72.

Wang $\mathrm{P}$ and liang (2010). Chemical composition and inhibitory effect on hepatic fibrosis of Danggui Buxue Decoction. Fitoterapia.81(7):793-798. 